\title{
Dartmouth's Master of Engineering Degree Program: Combining Engineering Design with Business Management
}

\author{
Benoit Cushman-Roisin, Elsa Garmire \\ Thayer School of Engineering, Dartmouth College
}

\begin{abstract}
In recognition of the growing need for industrial leaders with expertise in both technology and management, Thayer School of Engineering at Dartmouth College established in 1988 a managementoriented Master of Engineering (M. E.) degree program. Building on Thayer School's strength in interdisciplinary engineering education and its close relationship with Dartmouth's Tuck School of Business, this degree program is distinguished by its simultaneous emphasis on a broad graduate-level education in engineering, a working knowledge of the design process, and a practical understanding of the business environment. The absence of departmental barriers at Thayer School offers students the ability to bring an integrated view to the engineering design process.
\end{abstract}

The M.E. program is a rigorous two-year progression requiring 18 graduate-level courses in statistics, optimization, engineering design, engineering science, and business management. Through the Cook Engineering Design Center, corporations submit to Thayer School a wide variety of design problems, which become the basis of individual and group projects requiring close interaction between students and sponsoring companies. Further, opportunities are made available for all M.E. degree candidates to assume internships in industry prior to graduation. The selection of projects and internships is facilitated by the strong corporate and alumni network maintained by Thayer School.

\section{Introduction}

The economic success of the United States, and of the developed world in general, can be attributed unequivocally to industrial activity, which owes its very existence to both technological progress and business management. While industry has been able to rely for a long time on people separately trained in engineering and management, the ever increasing complexity of technology and its ever accelerating pace of development have now combined to require that managers, in various industrial sectors and particularly in the manufacturing sector, possess a practical understanding of technology. One way to satisfy this need has been to move engineers into managerial positions in their later career (the German model), another to include a technical component in the education of managers (the so-called Techno-MBA). Each approach is predicated on the belief that the missing educational component can be successfully retrofitted in the person's career: It is assumed that the engineer can acquire on the job and without formal training an adequate experience of business management to move into a managerial position, or that the MBA student with no prior education in engineering fundamentals can acquire with the help of a few courses an understanding of technical issues and a keen ability to recognize technological opportunities. However,

New technology requires more than just engineering. If you listen to the horror stories about how [U.S. companies] failed to adopt new technologies, it was always a management problem. ${ }^{1}$ 
Some have concluded that the reason behind the U.S. weakness vis-a-vis foreign competition is the fact that U.S. industries have inadequately addressed the role of technology in managing business enterprises. ${ }^{2}$ On a more positive note, others simply maintain that "big companies need managers wellversed in technical areas." 3 Such situation creates a distinct need for industrial leaders who have received a formal education in both engineering and management, and from an engineering rather than a business base.

Recognizing this need, the Thayer School of Engineering at Dartmouth College established in 1988 a management-oriented engineering degree program. This Master of Engineering (M. E.) program imparts to the student a broad graduate-level education in engineering, a working knowledge of the design process in all its aspects, and formal training in business administration. To do so, the program builds on the strengths of Thayer School's long-standing interdisciplinary approach to engineering education, its extensive ties with industry, and its close relationship with Dartmouth's Tuck School of Business.

The initiation of the program was made possible by a curriculum development grant from the Ford Motor Company. Over the years, enrollment figures have grown steadily, attracting high-caliber students, who upon graduation have very successfully embarked on an engineering- management career. Initially, students were recruited almost exclusively from Dartmouth's undergraduate degree program. Now, students are drawn from across the United States and a few foreign countries, and the program receives increasing visibility. ${ }^{4}$

\section{Program description}

The management-oriented M.E. degree program is conceived as a rigorous two-year progression requiring 18 graduate-level courses (Table 1). These include two courses in mathematics (statistics and optimization), three in engineering design, five in engineering science, and five in management The remaining three courses are complementary electives, taken at Tuck School, at Thayer School, or in any other department at Dartmouth such as computer science, chemistry, or Medical School.

The five required courses in engineering sciences include a mix of focus and breadth according to the student's own preference. The lack of departmental barriers at Thayer School has allowed the development of numerous courses spanning several engineering disciplines or fields of study that include collaborative projects with other Dartmouth programs, such as the Medical School. These interdisciplinary courses are ideal for M.E. students who wish to remain generalists while simultaneously acquiring knowledge in engineering at an advanced level.

The three-course design sequence consists of a two-term group project and a one-term individual project, both involving original design problems submitted by companies affiliated with Thayer School. On occasion, the second project is a continuation of the first or is initiated by an industrial experience such as an internship.

Of the 18 required courses, a minimum of five must be in engineering management. All M.E. students are required to take a three-course sequence in the fundamentals of management: finance, marketing and organizational behavior. These courses have been designed specifically for the M.E. program by Tuck School faculty, and include core business-school material adapted for the needs of engineering students. The remaining electives may be taken at Thayer School or with M.B.A. students at Tuck School. Most students elect to take more than a minimum of five courses in management.

Small classes and a high faculty-to-student ratio in each school combine to foster both class spirit and an extremely stimulating intellectual environment. 
Table 1. Structure of Dartmouth's M.E. Program

\begin{tabular}{|c|c|c|}
\hline $\begin{array}{r}\cdots \\
\text { Category }\end{array}$ & $\begin{array}{l}\text { Required } \\
\text { Number }\end{array}$ & $\begin{array}{l}\text { Course } \\
\text { Titles }\end{array}$ \\
\hline Mathematics & 2 & $\begin{array}{l}\text { Statistics \& Experimental Design } \\
\text { Optimization Methods }\end{array}$ \\
\hline $\begin{array}{l}\text { Engineering } \\
\text { Science }\end{array}$ & 5 & $\begin{array}{l}\text { All electives, in a specialization or } \\
\text { across the engineering spectrum }\end{array}$ \\
\hline $\begin{array}{c}\text { Engineering } \\
\text { Design }\end{array}$ & 3 & 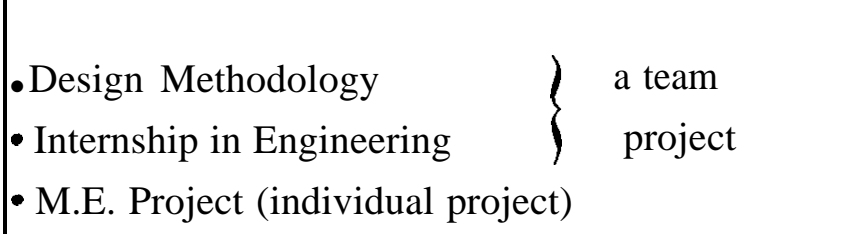 \\
\hline $\begin{array}{c}\text { Business } \\
\text { Management }\end{array}$ & 5 & $\begin{array}{l}\text {-Engineering Economy \& Financial Management } \\
\text { - Marketing } \\
\text { - Organizational Behavior } \\
\text {-Elective } \\
\text {-Elective }\end{array}$ \\
\hline Electives & 3 & $\begin{array}{l}\text { Courses to strengthen engineering and/or } \\
\text { management education, or to add an educational } \\
\text { dimension (e.g., computer science, chemistry, } \\
\text { biology, medicine, etc.) }\end{array}$ \\
\hline
\end{tabular}

Admission to the M.E. program is handled exclusively by the Thayer School of Engineering. Students with an accredited degree in engineering are eligible to apply and receive credit for work already completed that is equivalent to specific program requirements listed above. A student wellprepared in an engineering discipline may be able to receive sufficient credit to make possible completion of the program in as few as 12 months of study. Regardless of the student's own preparation, the bachelor degree and M.E. make a seamless educational program in engineering. Students holding bachelor dęgrees in mathematics or the sciences are also eligible for admission, but are usually required . to take additional undergraduate courses in engineering. Those are first placed in the Bachelor of 
Engineering (B.E.) degree program, an ABET-accredited undergraduate program, and are advised to ' take courses that maximize the overlap with the M.E. program. Once the B.E. program is completed (typically in 9 to 15 months, depending on the student's preparation), the M.E. degree is obtained in only one additional academic year.

\section{Practice-oriented aspects of the program}

The practice-oriented component of the M.E. program is two-fold, including a sequence of courses in engineering design, to provide experience in the creative engineering process, and a series of courses in business management, to instill a practical understanding of the business management and a familiarity with management tools. Both are meant to impart certain specific skills and problem-solving approaches that the graduate can use at once and also use as a basis for continued growth over one's career. In addition, students are strongly encouraged to assume a corporate internship during the intervening summer term usually arranged by Thayer School's corporate contacts.

\section{a. Design sequence}

Typically, a student graduating with a bachelor's degree in engineering has a good command of mathematics and is well versed in the fundamentals of engineering. Too often, however, the student suffers from an inadequate exposure to open-ended problems, a lack of experience in creative thinking, and a poor perception of the overall engineering process. Although this information is not new, evidence that the typical undergraduate preparation in engineering falls short of industry's expectations was again made manifest by a recent survey conducted by the College of Engineering and Technology at Brigham Young University. ${ }^{5}$ Their findings are summarized in Table 2.

At Dartmouth, however, Thayer School has long emphasized design as an integral part of its educational philosophy, with attention given to teamwork, communication skills, and the appreciation for the overall engineering process, from creative thinking to economic analysis. The graduate component of this curriculum is required of the M.E. students.

This so-called design sequence consists of three courses, which build on one another. The first course, Engineering Design Methodology \& Project Initiation, introduces the elements of the design process: Problem definition, search for multiple solutions, criteria for selection, detailed design, prototyping, design iterations, manufacturing, economic analysis, marketing, and environmental impact. During the first course students are also asked to select one project among several sponsored by companies via the Cook Engineering Design Center at Thayer School. Students are grouped in teams, and each team meets company representatives as the project gets underway.

During the second course, Internship in Engineering, student teams pursue and complete the project. During this time, students take two other courses and therefore remain in residence at Thayer School, seeking advice from faculty, and availing themselves of school facilities (machine shop, prototyping facility, computers, and assorted laboratories in optics, electronics, fluids, etc.). Numerous visits are paid to the sponsoring company. The writing of reports and delivery of oral presentations help students sharpen their communication skills.

The third course, Master of Engineering Project, takes the form of an individual engineering project addressing a practical need of a specific customer and proposing the means to satisfy it. On occasion, this project is an extension by the individual student of the earlier team project in which he/she was a member. More often, however, the basis for the individual design project originates from the preceding summer internship, if one took place. Students are encouraged to seek their own project and are therefore not offered a list of projects from which they could draw. The idea is to foster in them a spirit of enterprise and an ability to recognize opportunities. 
'- In the course of-these projects, students are brought into close contact with engineers and engineering management in participating companies. The resulting experience is an essential component of the program.

Table 2. Industrial perceptions of weaknesses in engineering graduates

- Technical arrogance

- No understanding of manufacturing processes

-A desire for complicated and "high-tech" solutions

-Lack of design capability or creativity

-Lack of appreciation for considering alternatives

- No knowledge of value engineering

-Lack of appreciation for variation

-All wanting to be analysts

-Poor perception of the overall project engineering process

- Narrow view of engineering and related disciplines

- Not wanting to get their hands dirty

- Considering manufacturing work as boring

- No understanding of the quality process

-Weak communication skills

-Little skill or experience working in teams

- Being taught to work as individuals

\section{b. Management courses}

Thayer School has developed management courses specifically designed for the M.E. program. All students must take three specific management courses: Engineering Economy \& Financial Management, Marketing, and Organizational Behavior. The first course is a 3-month version of a 6month course sequence at the Tuck School of Business, with examples and case studies drawn from the manufacturing sector. Similarly, the other two courses cover core business school material adapted and enhanced for the needs of engineering students. For example, the organizational behavior course emphasizes the management of engineering-project teams.

In addition to these required courses, students must take at least two additional courses in the area of engineering management. Courses in this category, which have been specifically designed for the M.E. program, are Production \& Inventory Control and Total Quality Management. The 'control' 
course is a uniniuge mix-of technical analysis of production and inventory onerations, blended with strategic overview of broader managerial issues. Compared to M.B.A. versions of this course, the Thayer control course provides greater technical depth and greater linkage between technology and other functions. The 'quality' course covers the basic and advanced concepts of total quality management and is strongly oriented toward application in the U.S. and Japanese manufacturing companies.

Most but not all of these courses are taught by professors of the Tuck School of Business, while attendance is restricted to engineering students. Further, M.E. students are allowed, and somewhat encouraged, to take additional courses offered by Tuck School to its M.B.A students. Popular courses are Entrepreneurship, Simulations, and various courses in manufacturing.

In essence, the management portion of the M.E. curriculum forms a mini M.B.A. program.

\section{c. Internships}

All Thayer School M.E. students are strongly encouraged to assume internships in industry prior to graduation. An active Placement Office provides a wide variety of means to help students take advantage of these opportunities - including maintaining a strong corporate and alumni network and an internship program.

Further, Thayer School has an active Corporate Advisory Board comprised of individuals representing nearly two dozen companies across a wide spectrum of industrial sectors. This board not only provides a communications link to the corporate world, informing students (and faculty) on current corporate trends, but also facilitates internship opportunities in their respective industries. Finally, some students prefer to rely on their own contacts to arrange an internship.

- While an internship is not a mandatory degree requirement, all students in the program to date have taken industrial internships. Most do so in the summer preceding their last year. Also, for many, the internship provides the topic for their individual design project and facilitates the search for employment at graduation.

\section{Recruitment and placement}

Since the Master of Engineering degree program was established to meet an existing need of industry, the placement of graduates is rather straightforward. Recruitment is another matter.

Because of its small size and its affiliation to a liberal-arts college, Thayer School suffers from insufficient external visibility. Some special efforts, therefore, had to be undertaken to recruit students into the M.E. program. A special poster is prepared annually and mailed to a variety of engineering schools across the country. The M.E. program is also featured on Thayer School's page on the world wide web (http//www.dartmouth.edu/thayer). Electronic queries are welcome and answered. All promising applications are followed by telephone calls or electronic messages. As for all other degree programs, Thayer School encourages interviews with prospective students.

At the beginning, the student population in the M.E. program was exclusively drawn from Dartmouth's ranks. Now, about half the students are continuing Dartmouth students, while the others come from a variety of institutions at home and abroad (Japan, South America and Europe). Almost all are continuing students, and very few have more than two years of professional experience.

By design, the M.E. program meets a real need of industry, and its graduates therefore face a very favorable situation. On average, students receive three job offers prior to graduation. Starting salaries are consistently higher than those offered to graduates with a Bachelor of Engineering degree (by 30\%) and with a Master of Science degree (by 20\%). M.E. graduates have assumed positions in a 
Wide range of companies, from well established corporations to start-ups, from international to small firms.

To streamline the placement process, Thayer School's full-service Placement Office maintains close contact with corporate recruiters and human resources personnel from a wide variety of industrial sectors. On-campus recruiting schedules, electronic job listings, and an active network of corporate contacts have provided exceptional placement opportunities for M.E. students.

Contacts with the earliest graduates reveal that they have assumed positions of industrial leadership, while more recent graduates are well on their way toward such positions. This indicates that the program is successfully accomplishing what it was designed to achieve: Educate people who can bridge the traditional divide between technology and management.

\section{Comparison with other institutions}

A small number of other institutions currently offer degree programs providing a simultaneous education in engineering and business management. These programs come in a variety of forms and names, almost as numerous as the institutions offering them, to the point of resisting any form of classification. Table 3 attempts to summarize information on each program (to the best of the authors' knowledge) for the purpose of comparison.

As one can quickly note, a couple of institutions (MIT and Rice) offer only a dual-degree program in collaboration between their engineering and business schools, others (Detroit-Mercy, Georgia Tech, Northwestern, Penn State, Tufts, and Wisconsin-Madison) offer single-degree programs, and still others (Cornell, Dartmouth, Michigan, Stanford, and Texas-Austin) offer both types. The engineering schools with single-degree programs rely to various degrees on their local business school, from full corporation (e.g., Northwestern) to not at all (Cornell and Stanford). In the latter type, the single-degree program is entirely housed in one or several disciplinary engineering departments. Tufts is singular, for its M.S. in Engineering Management is wholly the province of an institute separated from the engineering school (the Gordon Institute).

Some programs are designed for continuing students, while the others target returning professionals. Also, the mix of engineering and management curricular components vary from $33 \%$ to $80 \%$ management, the rest being engineering or project activity. The preferred mix appears to be $33 \%$ management, $33 \%$ engineering and 33910 electives/project. Some emphasize manufacturing while others do not. Finally, programs vary in length from one academic year for the non-thesis disciplinary master's program, to over two years for the dual-degree programs (M. S./M.B.A. and M. E./M. B.A.).

In all, it appears that every institution providing joint education in engineering and business management is doing so in an individual way, dictated by the kind of students it wants to attract, its relative desire to emphasize manufacturing, the size of its engineering school, and the relation between its engineering and business schools. In such environment, it is therefore not surprising to note that the M.E. program at Dartmouth's Thayer School of Engineering is unique. Thayer's M.E. program uniqueness stems primarily from the facts that, while the program is offered in close relation with the Tuck School of Business, Thayer School of Engineering governs the program, and that the engineering component is truly interdisciplinary.

\section{Conclusions}

In 1988, recognizing the growing need for industrial leaders with expertise in both management and technology, Thayer School established a management-oriented Master of Engineering (M. E.) degree program, combining its own particular strengths and its close relationship with Dartmouth's Tuck School of Business. 
Table 3. Comparison of existing engineering/management graduate degree programs

b

Remarks
within eng. dept.
with business school
with business school
emphasis on product develop.
disciplinary engineering
internship required
with Sloan School of Mgt.
6-mo. internship required
supported by industry
emphasis on manufacturing
emphasis on manufacturing
disciplinary engineering
emphasis on manufacturing
with business school
with business school
with school of administration
with Mech. Eng. Dept.
within Industrial Eng. \&
emphasis on manufacturing
thesis optional
emphasis on manufacturing
within Gordon Institute
interdisciplinary eng.


'- The Thayer School degree is distinguished by its simultaneous emphasis on a broad graduatelevel education in engineering, a working knowledge of design process in all of its aspects, and a practical understanding of the business environment. The absence of departmental barriers at Thayer School offers the distinctive advantage of not requiring that students narrowly compartmentalize themselves, but instead retain the ability to bring an integrated view to engineering design and manufacturing process.

While the program is judged successful, based on the excellent placement statistics of its graduates and on its positive revenue stream, Thayer School constantly searches ways to improve the program further. One thought under current consideration is whether a course in business law ought to be included. Proponents argue that all engineers and especially managers ought to know how to write a business contract and protect one's firm against lawsuits, while opponents claim that business law is a vast subject, by-and-large the province of corporate lawyers, not managers.

At this time, Thayer School is also exploring the possibility of offering, within the existing M.E. program, a concentration in environmental issues. The cross-cutting environmental theme would span engineering (air and water quality, sustainability) and business (natural resources management, industrial ecology), with an extension to environmental law.

\section{Acknowledgment}

The authors wish to thank their colleagues at Thayer School, who have graciously shared their experience with the M.E. program, particularly former dean Charles E. Hutchinson and professor Daniel R. Lynch. The comparison with similar programs at other institutions was greatly facilitated by the research made by Emerson B. Houck, member of the Corporate Advisory Board of Thayer School.

\section{References}

1 Lester Thurow, quoted in “Now Sloan's MBA's will be Masters of Technology”, Business Week, 13 April 1987.

2 Richard Migogna, quoted in “Technology Management: New Kind of MBA”, Engineering Times, Vol. 15, No. 1, January 1993.

3 Urban Wemmerlov, quoted in "Engineering is Re-engineered into a Team Sport”, Wall Street Journal, 2 May 1995.

4 Nancy Fitzgerald, “Mastering Engineering”, ASEE Prism, pp. 24-28, January 1996.

5 Robert H. Todd, Carl D. Sorenson, and Spencer P. Magleby, "Designing a Senior Capstone Course to Satisfy Industrial Customers”, J. Engineering Education, Vol. 82, No. 2, pp. 92-100, 1993.

Benoit Cushman-Roisin is professor of engineering and associate dean of the Thayer School of Engineering at Dartmouth College. He teaches and conducts research in the area of environmental engineering.

Elsa Garmire is professor of engineering and dean of the Thayer School of Engineering at Dartmouth College. Her research area is lasers and electro-optics. 